\title{
ОРГАНІЗАЦІЯ РОБОТИ З ЛІНГВО- ТА ЛІТЕРАТУРОЗНАВЧОДИДАКТИЧНОЮ ТЕРМІНОЛОГІЕЮ ЯК ЗАСІБ ФОРМУВАННЯ ДИДАКТИЧНОЇ КОМПЕТЕНТНОСТІ МАЙБУТНІХ УЧИТЕЛІВ ФІЛОЛОГІЧНИХ СПЕЦАЛЬНОСТЕЙ
}

\footnotetext{
У статті здійснено спробу розкрити шляхи організації роботи з лінгво- та літературознавчою термінологією як засобу формування дидактичної компетентності майбутніх учителів філологічних спечіальностей. Обгрунтовано взаємозалежність предметних (фахових) компетенцій і дидактичної компетентності майбутніх фахівців.

Ключові слова: лінгво- та літературознавчодидактична термінологія, майбутні учителі філологічних спеціальностей, предметна компетенція, дидактична компетентність.
}

В статье сделана попытка раскрыть пути организации работы с лингво- и литературоведческидидактичской терминологией как способа формирования дидактической компетентности будуших учителей филологических спечиальностей. Обоснована взаимосвязь предметных (профессиональных) компетенций и дидактической компетентности будущих профессионалов.

Ключевые слова: лингво- и литературоведческидидактическая терминология, будущие учителя филологических специальностей, предметная компетенция, дидактическая компетнтность.

The article attempts to uncover ways of working with linguistic and литературоведческидидактичской terminology as a way of forming the didactic competence of future teachers of philological specialties. Proved the relationship of subject (professional) competences and didactic competence of future professionals.

Key words: Linguistic and литературоведческидидактическая terminology, future teachers of philological disciplines, subject expertise, teaching kompetntnost.

Модернізація вітчизняної вищої філологічної освіти одним із актуальних напрямів визначає формування дидактичної компетентності майбутніх учителів філологічних спеціальностей, необхідним компонентом якої є знання фахової лексики. 3 огляду на зазначене вище професійне засвоєння фахової термінології в підготовці вчителів філологічних спеціальностей є однією 3 найважливіших проблем сучасної педагогічної освіти. Для задоволення професійних потреб та забезпечення належної культури фахового спілкування майбутньому вчителеві-словесникові слід засвоїти значну кількість нових термінів, що в останні десятиліття значною мірою зазнали структурно-семантичних трансформацій та оновлення.

Лінгводидактична й літературознавчодидактична термінологія, поряд із психологічною, дидактичною, лінгвістичною, літературознавчою тощо, складають фаховий словник учителя філологічних спеціальностей; володіння нею свідчить про глибоке розуміння професійних понять і явищ. Водночас процес опрацювання лінгво- й літературознавчодидактичної термінології у вищих навчальних закладах педагогічного профілю - досить складний, що зумовлено стрімким розвитком шкільної освіти й методичної науки в останні десятиліття, зміною пріоритетів і підходів до навчання мови й літератури, пов'язаний не тільки з вивченням профільних курсів, курсів методики української мови й літератури, а й суміжних із ними дисциплін.

Загальні питання термінології й термінознавства порушували у своїх працях мовознавці І. Білодід, Р. Будагов, В. Виноградов, В. Винокур, Б. Головін, В. Даниленко, П. Дудик, М. Жовтобрюх, М. Зарицький, I. Ковалик, Т. Панько, О. Пономарів, О. Реформатський, Л. Симоненко, О. Суперанська, С. Шелов та інші. Лінгвістичні основи роботи з фаховою термінологією розглядали також методисти Л. Барановська, О. Горошкіна, В. Павлов, М. Пентилюк， М. Шкільник. Попри наявність праць у галузі навчальної лексикографії та формування культури професійного мовлення, проблема засвоєння лінгводидактичної й літературознавчодидактичної термінології студій літературознавчодидактичної термінології студентами філологічних спеціальностей не була предметом спеціального дослідження, що свідчить про актуальність порушеного питання.

Mema cmammi - розкрити шляхи організації роботи 3 лінгводидактичною й літературознавчодидактичною термінологією як засіб формування дидактичної компетентності у змісті фахової підготовки майбутніх учителів філологічних спеціальностей.

Лінгводидактика означає науку про загальну теорію навчання мови як природної системи комунікативних знаків і правил їх функціонування [1; 7]; літературознавча дидактика, відповідно, про загальну теорію навчання літературі як різновиду мистецтва, мистецтва слова, що відображає дійсність у художніх образах, створює нову художню реальність за законами краси [3]. Лінгводидактика й літераратурознавча дидактика $-\epsilon$ вужчими поняттями, охоплюють лише теоретичні питання методики і входить до складу загальної дидактики, що враховує й специфіку викладання кожної окремої мови й літератури, особливості роботи над тим чи іншим розділом програми тощо $[1 ; 6]$. Оскільки загальні закономірності навчання мов, вивчення літератури вивчаються лінгводидактикою й літературознавчою дидактикою, то предметну методику С. Гончаренко розглядає як «часткову дидактику», до змісту якої входить установлення значення навчального предмета, його змісту, завдань і місця в системі шкільної освіти, вироблення відповідних методів, прийомів, засобів і форм навчання. 
Отже, лінгводидактика й літературознавча дидактика та методика навчального предмета перебувають у родо-видових відношеннях. Формування дидактичної компетентності майбутніх учителів філологічних спеціальностей грунтується на основі підпорядкованих їй рівнів - предметних (фахових) компетенцій; відповідно, $є$ поетапним процесом засвоєння й розуміння лінгво- й літературознавчодидактичної термінології, розвиток якої, своєю чергою, характеризується такими логічно вмотивованими закономірностями [2; 5]:

1. Функціонування - виникнення назви нових лінгво- й літературознавчодидактичних понять, що створюються в пошуковій діяльності методистів. Вони становлять прототерміни і втілюються в словесні одиниці, що йменуються номенами, професіоналізмами, термінолексемами.

2. Фіксація - попереднє випробування термінів шляхом уживання їх у наукових, науковометодичних та навчальних публікаціях; здійснення попереднього відбору термінів, зіставлення й узгодження різних прототермінів.

3. Уніфікація термінів - укладання лінгво- та літераттурознавчодидактичних словників та довідників, експертний відбір, звуження термінологічного реєстру, внаслідок чого терміни набувають рекомендаційного статусу. Результатом уніфікації термінів $є$ виникнення лінгводидактичної термінології як сукупності термінів лінгво- та літературознавчодидактики.

4. Стандартизація, у процесі якої термінам надається нормативний, директивний статус, i виникає терміносистема як уніфікована система термінів, піддана науковому опрацюванню та впорядкуванню.

Отже, сучасний стан лінгво- й літературознавчодидактичної термінології $\epsilon$ результатом багаторічної роботи вчених-методистів та вчителів-практиків, які працювали над їі регулюванням й упорядкуванням. Лінгводидактична термінологія перебуває на етапі свого розвитку, що ускладнює процес засвоєння лінгво- та літературознавчодидактичної лексики майбутніми вчителями філологічних спеціальностей. Наведені вище міркування переконують у необхідності систематизації й подальшого розроблення лінгво- й літературознавчодидактичної термінології.

В основу поділу лінгво- й літературознавчодидактичних термінів на групи за першим критерієм (джерелами виникнення) нами покладено класифікацію М. Львова [6, с.5] і виокремлено такі групи:

1. Загальнодидактичні терміни - позначають поняття, запозичені з педагогіки і спільні для різних галузей дидактики, тобто вживаються в методиках викладання різних предметів (урок, метод $i$ прийом навчання, програмоване навчання, інтерактивні технологї, лабораторні роботи, навчальна програма, практикум, індивідуальна і самостійна робота). Педагогічні поняття, засвоєні методикою, стають вужчими, конкретизуються, поділяючись на види й підвиди $[4$, с. 6]. Зокрема, дидактичне поняття

- уміння учнів в методиці членується на 1) мовні, нормативні, комунікативні; 2) уміння коментованого й інтерпретаційного читання;

- компетентність - 1) мовну, мовленнєву, комунікативну, соціокультурну; 2) соціальні, мотиваційні функціональні компетентності.

Загальнодидактичні терміни складають систему понять, у якій ступінь узагальненості лінгво- й літературознавчодидактичних понять значно нижчий, ніж у родових дидактичних понять.

2. Методично-лінгвістичні (методично-літературознавчі) терміни - поняття й терміни, запозичені методикою зі словника науки, що викладається, тобто 3 лінгвістики й літературознавства, а також із суміжних з ними наук: психолінгвістики, філософії, естетики, культурології тощо:

1) частина мови (іменник, прикметник) у курсі української мови, етапи вивчення синтаксису, вивчення морфології в школі;

2) жанр байки у шкільному курсі украӥнської літератури (Л. Глібов), образна система художнього твору (автологічний і металогічний образи; літературний й історичний образи, вивчення українськой дитячої літератури в школі.

Методично-лінгвістичні (методично-літературознавчі) терміни утворюють групи:

1. Назви об'єктів вивчення, тобто розділів, тем і підтем шкільного курсу мови (літератури). Наприклад:

1) поняття прикметник є предметом лінгвістики, лінгвометодичне поняття прикметник $y$ икільному курсі української мови - предметом вивчення в школі, елемент змісту навчання;

2) поняття народна казка, літературна казка $\epsilon$ предметом літературознавства, літературознавчодидактичне поняття - народна й літературна казка в шкільному курсі украӥнської літератури.

2. Назви мовознавчих і літературознавчих понять, явищ, щзо не вивчаються в школі, але необхідні вчителеві для розв'язання методичних завдань і розвитку методики в цілому. До другої підгрупи належать такі поняття, що не входять до шкільного курсу мови (літератури):

1) етимологічний аналіз, принциии украӥнської орфографії, фонема, дискурс, адвербіалізація, прономіналізація, транспозиція, компаративні відношення, валентність дієслова, внутрішня $i$ зовнішня транспозиція відмінкових форм, словозмінні $і$ класифікаційні елементи в категорії числа іменника, міжсівнева (морфолого-синтаксико-словотвірна) категорія ступенів порівняння $i$ актантна деривація тощо; 
2) документально-реалістичний напрям в украӥнській драматургї 20-30-х років, абстрактносимволічна романтика української драматургії 20-30-х років; кларнетизм, міфологем ний код, орієнталістика, панторима, жанр стансів тощо. Зауважимо, що вживання термінів розглядуваної групи останнім часом суттєво зросло, що пов'язуємо із реформуванням шкільної освіти, новими підходами, аспектами викладання гуманітарних предметів у школі, подальшого розроблення змісту навчальних предметів.

3. Група термінів, що перебувають у тісних взаємозв'язках із психологією:

1). Мовленнєвознавчі (психолінгвістичні) терміни мають комунікативну і психолінгвістичну природу (комунікативна компетенція, говоріння, ситуація спілкування, адресат, адресант мовлення, мовленнєва дія аудіювання, читання, говоріння, спілкування, дискурсивне мовлення тощо); терміни розкривають психологію мовлення, спілкування, формування навичок мовленнєвої діяльності. Зауважимо, що група мовленнєвознавчих термінів останнім часом активно поповнюється, оскільки комунікативно-діяльнісний аспект нині є пріоритетним у навчанні української мови.

2). Психологолітературознавчі терміни розкривають психологію розуміння й інтерпретації тексту художньої літератури (алюзія, психологізм художнього твору, екзестенціоналізм як напрям художньої літератури, психологія творчості, рецептивна естетика, рецептивна поетика, рефлексія сприймання твору). Зауважимо, що окреслена підгрупа термінів останнім часом поповнюється відповідно до визначальних нині напрямів розвитку дидактичної філології - грунтування на естетичних концептах літературознавчої полеміки (культурологічні, літературознавчі дискусії), екзистенційно-діалогічних основах викладання української літератури в навчальних закладах.

4. Психологодидактичні терміни позначають психологічні поняття (розвиток логічного мислення учнів, творчий розвиток на уроиі мови (літератури), проблемне вивчення мовних (літературознавчих) явищ, моторна пам'ять, абстрактне мислення). Розвиток системи психологодидактичних термінів пов'язаний із необхідністю врахування психологічних умов навчання гуманітарним предметам.

5. Етнолінгводидактичні терміни (рідна мова (література), ментальність, національна специфіка літератури, етнічно-зорієнтована мовна особистість, національний колорит мовлення, етнонім, національно-мовна картина світу, образ, символ, етнофор, етнографізм, українознавчий nidxid) розширюють наші уявлення про культурозумовленість мовної картини світу, соціокультурну компетенцію, соціокультурну змістову лінію в навчанні мови й літератури.

6. Власне лінгво- та літературознавчодидактичні поняття й терміни [3; 4]:

1) диктант (зоровий, слуховий), орфографічне правило, творчий переказ, переказ-переклад, коментоване письмо, граматичний розбір, орфограма, пунктограма, редагування, лінгвістичний аналіз тексту, лінгвістичний експеримент;

2) головний і другорядний персонаж літературного твору, авторська оповідь, прозова і віршована мова казок, сюжет і композиція, основна ідея художнього твору, жанр балади, повісті, роману.

Організація навчальної діяльності майбутніх учителів філологічних спеціальностей, спрямована на формування дидактичної компетентності, може передбачати такі форми роботи:

Робота 3 лінгводидактичною термінологією:

1. Розкрийте значення термінів (термінологічних словосполучень): субстантив, субстантивація, іменники pluralia tantum, маскулізм, фемінатив, потенційний рід іменників, бінарне протиставлення роду, іменники з нульовою флексією, номінатив, генітив, датив, акузатив, локатив, локатив. Наведіть приклади мовних явищ. Подайте зіставний аналіз аспектуальності у вивченні наведених мовних явищ у шкільному курсі української мови.

2. Підготуйте фрагмент уроку вивчення нового матеріалу на тему «Іменник як самостійна частина мови» (6 клас), у якому передбачте роботу над новими для учнів поняттями, термінами й визначеннями.

3. Які методи і прийоми передбачені в аналізованому плані-конспекті для введення нових понять? Наскільки виправданим $є$ використання саме цих методів? Які зміни у структурі уроку сприяли б, на Вашу думку, його покращенню? [10].

4. Укладіть тлумачний словник-мінімум лінгвістичної та мовленнєвознавчої термінології для учнів 6-го класу. У якому класі чинна шкільна програма передбачає первинне ознайомлення 3 кожним із цих термінів? [9, с. 50-54].

5. Доберіть по 2 зразки завдань до кожного типу вправ (пропедевтичні, кумуляційні, тренувальномовленнєві, творчі) для 6 класу («Іменник як самостійна частина мови»).

Робота 3 літературознавчодидактичною термінологією:

1. Розкрийте значення термінів (термінологічних словосполучень): лінгвістичний аналіз тексту, зображально-виражальні засоби, конотативне значення, денотативне значення, експресія, декскриптивна функиія, символ, образ, автологічний і металогічний образ, концепт, механізми перетворення образу на символ (конщепт), автобіографічний твір. Наведіть приклади літературознавчих явищ. Подайте зіставний аналіз аспектуальності у вивченні наведених літературознавчих явищ у шкільному курсі української літератури. 
2. Підготуйте фрагмент уроку вивчення нового матеріалу на тему «Михайло Стельмах «Гусилебеді летять»(7 клас), у якому передбачте роботу над новими для учнів поняттями, термінами й визначеннями.

3. Які методи і прийоми передбачені в аналізованому плані-конспекті для введення нових понять? Наскільки виправданим є використання саме цих методів? Які зміни у структурі уроку сприяли б, на Вашу думку, його покращенню?

4. Укладіть тлумачний словник-мінімум літературознавчої термінології для учнів 7-го класу. У якому класі чинна шкільна програма передбачає первинне ознайомлення 3 кожним із цих термінів? [8].

5. Ознайомтеся 3 лінгвістичним аналізом текстового фрагменту. Накресліть власні методичні кроки розкриття власне розуміння образу гусей-лебедів під час вивчення художнього твору на уроці.

Символ лебедів водночас як персонаж із дитячої казки містить конотат майбутнього. При цьому майбутнього можна досягти на лебединих крилах, отже, йдеться про внутрішній імператив відкритості, щирості, вірності ідеалам, що є запорукою реалізації й утвердження загальнолюдських цінностей (майбутне - заметіль цвіту і добрий розум): 3 того вечора я часто приходив у комбід до дядька Себастіана, $i$, коли він мав час, ми разом читали якусь книгу чи гомоніли про всяку всячину, а найбільще про те, що буде попереду, коли згине коріння й насіння воєн, людської ворожнечі $і$ злиднів, коли не хурделиия свинцю, а заметіль цвіту буде огортати людину і добрий розум увійде в кожну оселю. Дядько Севастіана перед собою і мною велич надій, $і$ на їхніх лебединих крилах летіла в майбутне моя дитяча душа.

5. Доберіть по 2 зразки завдань для 7 класу («Михайло Стельмах «Гуси-лебеді летять...») на основі спостереження над мовним матеріалом. Відповідно до вимог програми укладіть власні фрагменти, що розкривають дитячі образи повісті [8, с. 46-47]:

Повість «Гуси-лебеді летять...» містить провідні комбіновані світоглядні «дитячі» образи повісті: небо - земля; небо - зорі; земля - вода (річка, струмок, джерельче); земля - пора року.

Образ небо - земля подано як гармонійно відтворювану дійсність, світоглядними орієнтирами якої $\epsilon$ національні й загальнолюдські цінності, конкретизовані в уявленні про красу людського життя, його вияви, крізь призму так побудованого символу людські взаємини сприймаються як органічні, співвідності із красою світу. Складові образу посилюються шляхом розгортання частковими компонентами (небо - сонце, птиця; земля - поле): Ось уже коні беруть на другу вулицю, ось уже востанне промайнули голови молодят, а ми дивимося і дивимося $і$ на дальні прищімлені весною поля, і на сонце, і на вітряк - оту селянську птицю-казку, щз все збирається злетіти в небо, та не може розлучитися із землею - Якою буде ї̈ доля? - не знати в кого, чи в сонця, чи в землі, питається мати.

Емоційність досягається конотатами радість, відкритість, щирість (сонще); мрійливість, закоханість (птиия-казка); прагнення, віра (небо); єдність прагнення чогось $і$ суму за втраченим (злетіти - розлучитися).

Складова образу небо розгортається частковим - символом лебедів. Спостерігаємо реалізацію конотатів дива (таємниці), багатоголосся навколишнього світу (дзвін крил, лебедина пісня, смичок піднебесся); чистоти (відкритості, щирості, теплоти) дитячої душі (сумний дзвін крил у душі; на лебединих крилах летіла дитяча душа). Емоційність створюється прийомом кольоропису: білий колір реалізує значеннєві відтінки (біле підхмар'я - широта неба, широта світогляду; святково вбрані хмари - піднесеність; лебедині крила - прагнення, мрія, політ). Окремо звертаємо увагу на активність звукових асоціацій (дзвін крил - дзвін піднебесся - дзвін душі), що засвідчує паралелізм на рівні реальність - людина: $А$ в ией час наді мною твориться диво: хтось невидимий смичком провів по синьому піднебессі, по білих хмарах, $і$ вони забриніли, як скрипка; За високою стрункою дзвіницею, що теж поривається вгору, десь у білому підхмар'ї зникають лебеді, але дзвін їхніх крил ще озивається в мені, а може, то вже озиваються розбуджені дзвони на дзвіниці; ... Найбільме мені шкода лебедів і того сумного дзвону, що натрусили вони мені в душу. I шкода, щцо осінь моя минає в полях, у дібровах, а не в школі; I враз над моїм смутком обізвались бентежсні звуки далеких дзвонів. Ми з Любою підіймаємо голови до неба, до святково білих хмар $і$ бачимо, як прямо із них вилітають лебеді $і$ натрушують на хати, на землю $і$ в душу свою лебедину пісню. I хороче, $і$ дивно, $і$ радісно стає мені, малому, в ичім світі... А лебеді летять, летять.. над моїм дитинством... над моїм життям!....

Якість гуманітарної освіти студентів-філологів насамперед визначається рівнем засвоєння ними професійно орієнтованих дисциплін і володіння відповідною фаховою термінологією. Процес професійного засвоєння студентами-філологами лінгво- і літературознавчодидактичної термінології становить собою чітку систему, що складається з лінгвістичного, літературознавчого, психологічного й методичного компонентів, які сприяють формуванню дидактичної компетентності студентівфілологів на грунті предметних компетенцій, забезпечуючи професійну спрямованість навчального процесу, розуміння студентами взаємозалежності формування поняття й засвоєння лінгво- i літературознавчодидактичних термінів, міжпредметних і внутрішньопредметних зв'язків. 
Пропонована методична система професійного засвоєння лінгво- та літературознавчодидактичної термінології студентами філологічних факультетів може бути використана як альтернативна до методичних розробок, упроваджених на філологічних факультетах вищих закладів педагогічної освіти.

Системна робота студентів 3 фаховою термінологією сприяє формуванню дидактичної компетентності майбутніх філологів; забезпечує цілеспрямований характер взаємодії педагога й студента, залучення студентів до когнітивної діяльності, цілеспрямовану організацію пізнавальної діяльності студентів, взаємозалежність міцності й глибини засвоєння матеріалу та регулярного організованого повторення його й уведення до складу вивченого раніше.

Перспективу подальших наукових розвідок убачаємо в розробленні альтернативної методичної системи навчання майбутніх учителів-словесників загальнонаукової термінології в процесі вивчення як профільних, так і варіативних фахово орієнтованих навчальних курсів.

\section{Література}

1. Гончаренко С.Український педагогічний словник / Семен Гончаренко. - К. : Либідь, 1997. - 374 с. 2. Зарицький С. Актуальні проблеми українського термінознавства : [підручник] / С. Зарицький. - К. : ІВЦ «Політехніка»; ТОВ «Фірма періодика», 2004. - 128 с. 3. Лингвистический энциклопедический словарь / гл. ред. В.Н. Ярцева. - М. : Сов. Энциклопедия, 1990. - 685 с. 4. Літературознавчий словник-довідник / Р. Т. Гром'як, Ю. І. Ковалів та інші. - К. : ВЦ «Академія», 1997. - 752 с. 5. Лотте Д. Как работать над терминологией: Основы и методы / Д. Лотте. - М. : Просвещение, 1968. - 76 с. б. Львов М. Словарьсправочник по методике русского язика / М. Львов. - М. : Просвещение, 1988. - 240 с. 7. Словник-довідник 3 української лінгводидактики : [навч. посіб.] / кол. авторів за ред. М. Пентилюк. - К. : Ленвіт, 2003. - 149 с. 8. Украӥнська література 5-12 класи : програма для загальноосвітніх навчальних закладів. - Київ ; Ірпінь, 20 200 с. 9. Українська мова 5-12 класи : програма для загальноосвітніх навчальних закладів. - Київ ; Ірпінь, 20 176 с. 10. Шанский Н. М. О некоторых актуальных вопросах методики русского языка как науки / Н. М. Шанский // Проблемы совершенствования содержания и методов обучения русскому языку в 4-8 классах. - M., 1969. - C. 3 - 12. 